\title{
Potential and Use of Nitrate in Agricultural Purposes
}

\author{
Anupam Khajuria, Shinjiro Kanae \\ Department of Mechanical \& Environmental Informatics, Tokyo Institute of Technology, Tokyo, Japan \\ Email: khajuria.a.aa@m.titech.ac.jp
}

Received February 26, 2013; revised March 26, 2013; accepted April 20, 2013

Copyright (C) 2013 Anupam Khajuria, Shinjiro Kanae. This is an open access article distributed under the Creative Commons Attribution License, which permits unrestricted use, distribution, and reproduction in any medium, provided the original work is properly cited.

\begin{abstract}
With the excess use of nitrogen, a number of global and regional factors need to be addressed. Nitrate contamination of agricultural water leads to a number of environmental problems. During the twentieth century, the human being has used increasingly more reactive nitrogen, intentionally as fertilizer. The revolution in agricultural production is possibly increase by the use of nitrogen fertilizers. The inorganic nitrogen fertilizers are an essential input for maintaining high crop yield. This article discusses the origin and role of nitrogen in the environment. The potential and use of nitrogen as fertilizer for groundwater and surface water quality resources in agricultural purposes are discussed.
\end{abstract}

Keywords: Nitrogen; Environment; Problem; Groundwater; Surface Water

\section{Introduction}

The global nitrogen represents one of the most essential nutrients that sustain life on earth even it is a major pollutant in the ecosystem. Moreover, the excessive use of nitrogen as a fertilizer disturbs the biogeochemical nitrogen cycle, resulting environmental problems. Human induced changes in global nitrogen flows significantly affect the sustainability of food production and the health of the environment. The availability of nitrogen have been a driving force behind the green revolution but excess use and inefficient practices can lead to over-enrichment, causing soil acidification and groundwater pollution. These problems are set to intensify as population, urbanization and increase food demand. There is a range of challenges to achieve food, water and energy security for rapidly growing population and developing strategies for minimizing the negative impact of excess use of nitrogen in the ecosystem. In this article, we discuss: (a) origin and role of nitrogen; (b) effect of nitrogen; (c) potential of nitrogen problems in water resources.

\section{Origin and Role of Nitrogen}

Nitrogen is present in air, water, soil, rocks, plants and animals. In the atmosphere, nitrogen exits mainly as $\mathrm{N}_{2}$ which comprises $78 \%$ of the atmospheric gases. The non-reactive $\mathrm{N}_{2}$ gas must be converted through fixation to reactive forms such as ammonia, amino acids and proteins before being available to most life forms. Nitrogen occurs in many different chemical forms, the various processes of water transport provide a range of impacts with respect to water resources [1]. In the hydrosphere, nitrogen exits as soluble organic or inorganic nitrogen. Nitrogen is transported in precipitation, groundwater flow and surface water flow. Nitrogen in precipitation occurs as $\mathrm{NH}_{3}$ and $\mathrm{NO}_{3}$. More typically, precipitation soaks into the ground adding nitrate and ammonium, which also involves soils, decaying plant and animal matter, microbes, and living plant roots. Many chemical and physical factors control the rate at which nitrogen enters and leaves, including soil type, temperature, microbial activity, and plant growth. The $\mathrm{NO}_{3}$ form is soluble in water and mobile in soil, while $\mathrm{NH}_{3}$ is adsorbed to soil particles and immobile. $\mathrm{NO}_{3}$ dissolved in water can readily leach through the soil profile into groundwater [2]. The sediment in runoff water is the most common pollutant of surface water. $\mathrm{NO}_{3}$ is moved with the runoff water, which is the most common pollutant of surface water [3]. Nitrogen is present in many different forms and is continually changing from one molecule to another. This process of change and movement is commonly referred to nitrogen biogeochemical cycle. The nitrogen biogeochemical cycle involves some abiotic processes such as deposition of nitrogen compound, ammonia volatilization and nitrate leaching. The global sources of nitrogen in anthropogenic and natural factors are shown in Figure 1.

The nitrogen processes of fixation, mineralization and 
nitrification increase the plant available. Nitrogen denitification result in permanent or temporary losses from the root zone of plants. Fixation: It refers to the conversion of atmospheric nitrogen to a plant available form. This occurs either through an industrial process, as in the production of commercial fertilizers or a biological process, as with legumes such as alfalfa and clover. Nitrogen fixation requires energy, enzymes and minerals, so if a plant available form of nitrogen is present, the crop will use it instead of fixing it from the air.

$$
\mathrm{N}_{2} \rightarrow \mathrm{NH}_{3} \rightarrow \mathrm{R}-\mathrm{NH}_{2}
$$

When legumes are tilled into the soil, the nitrogen stored in their roots is released and made available to the next crop or lost to the environment, depending on management. In mixed legume-grass stands, the grass can utilize nitrogen fixed by the legumes. If the legume-grass stand has $25 \%$ or more legumes, no additional nitrogen is needed.

Mineralization: It is the process by which microbes decompose organic nitrogen from manure, organic matter and crop residues to ammonium.

$$
\mathrm{R}-\mathrm{NH}_{2} \rightarrow \mathrm{NH}_{3} \rightarrow \mathrm{NH}_{4}^{+}
$$

Because it is a biological process, rates of mineralizetion vary with soil temperature, moisture and the amount of oxygen in the soil (aeration). Mineralization readily occurs in warm $\left(68-95^{\circ} \mathrm{F}\right)$, well-aerated and moist soils.

Nitrification: The process by which microorganisms convert ammonium to nitrate to obtain energy. Nitrate is the most plant available form of nitrogen, but is also highly susceptible to leaching losses. Nitrification is most rapid when soil is warm $\left(67-86^{\circ} \mathrm{F}\right)$, moist and well-aerated, but is virtually halted below $41^{\circ} \mathrm{F}$ and above $122^{\circ} \mathrm{F}$.

$$
\mathrm{NH}_{4}^{+} \rightarrow \mathrm{NO}_{2}^{-} \rightarrow \mathrm{NO}_{3}^{-}
$$

Denitrification: It occurs when nitrogen is lost through the conversion of nitrate to gaseous forms, such as nitric oxide, nitrous oxide and dinitrogen gas. De-nitrification is common in poorly drained soils.

$$
\mathrm{NO}_{3}^{-} \rightarrow \mathrm{NO}_{2}^{-} \rightarrow \mathrm{NO} \rightarrow \mathrm{N}_{2} \mathrm{O} \rightarrow \mathrm{N}_{2}
$$

\section{Effect of Nitrogen on Environment}

All positive and negative consequences are including in the balance of nitrogen in the environment. The positive consequences are improved crop yields whereas negative consequences especially water resource depletion. The groundwater and surface water are contaminated under various irrigation activities. Reduced forms of nitrogen, such as ammonia, ammonium and amines also play an important role in atmospheric pollution, deposition, soil and water pollution [1]. The major sources, sinks, and transport mechanisms for the exchange of nitrogen be-

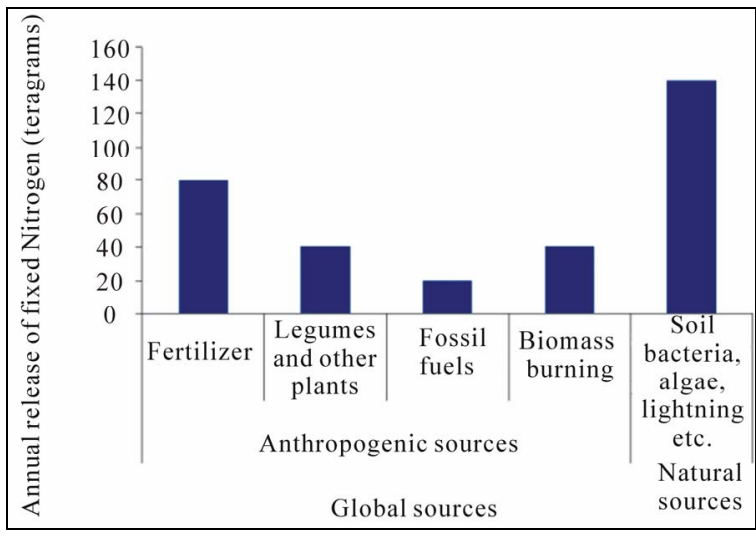

Figure 1. Global source of nitrogen. Source: [1].

tween the atmosphere and the biosphere of the earth are reasonably well understood. Reactive nitrogen is a major contributor to photochemical smog, fine particulate pollution, ecosystem acidification and fertilization, coastal eutrophication and global warming [4]. For ecosystems, smog can damage crops and forests; increased fertilization and/or acidity from nitrogen additions causes multiple ecological changes in both terrestrial and aquatic ecosystems that can result in biodiversity shifts, favor invasive alien species and damage the economic base of environmental systems. Reactive nitrogen affects the global balance of several greenhouse gases, including carbon dioxide $\left(\mathrm{CO}_{2}\right)$, nitrous oxide $\left(\mathrm{N}_{2} \mathrm{O}\right)$ and methane $\left(\mathrm{CH}_{4}\right)$ [5].

\section{Effects of Nitrogen on Human Health}

Changes in nitrogen use affect human health. On the positive side, high yield food is produced from nitrogen fertilizer is clearly a massive public health benefit, both in terms of production of food produced and its average protein content. Furthermore, fertilizer will contribute to increase-production of biofuels needed for a sustainable energy production.

Nitrogen-related air pollution is linked to higher rates of cardio-pulmonary ailments and overall mortality in urban areas [6]. There is highly concern about the potential health impact of high levels of nitrate in drinking water. Ecological feedback to excess nitrogen may inhibit crop growth, increase allergenic pollen production, and possibly increase in the prevalence of several parasitic and infectious human diseases like cholera. The connection of reactive nitrogen in air causes several types of cancer.

\section{Nitrate: Groundwater Contamination}

Natural factors: Nitrate is the most mobile form of nitrogen which is high soluble and negative charge.

1) Soil aeration affects mineralization, immobilization, 
and denitrification. Well-aerated soils provide a favorable environment to convert $\mathrm{N}$ to $\mathrm{NO}_{3}$ with only minimal loss through denitrification;

2) Soil texture influence groundwater contamination from nitrogen in several ways. The ease of drainage through coarse-textured soil often results in conditions that favor the $\mathrm{NO}_{3}$ in the form of nitrogen;

3) Groundwater recharge is controlled by the amount of water that infiltrates the soil surface and percolates beyond the rooting zone of plants.

Anthropogenic factors: Anthropogenic or human factors have the greatest influence on nitrogen availability.

1) Human activity includes a wide variety of nitrogen sources that create contamination problems related to animal production, production, storage and use of synthetic fertilizers and human waste disposal;

2) Cultivated land includes areas of cropped fields that are generally tilled to some degree, have an unnatural composition of vegetation that lacks diversity, and often have fertilizer routinely added [7];

3) Crops have different patterns of uptake that fulfill their requirement of nutrients and water. Nutrient and water uptake by the crop during the growing season affect availability of $\mathrm{NO}_{3}$ in the soil;

4) Irrigation involves growing crops with high nutrient requirements and/or shallow rooting depths and increasing the potential for $\mathrm{NO}_{3}$ leaching.

\section{Nitrate: Surface Water Contamination}

Natural factors: Several forms of nitrogen are likely to pose surface water contamination problems.

1) Surface water proximity to sources of nitrogen has been recognized as one of the most important factors that affects contamination;
2) Mobilization in solution for surface water transport of $\mathrm{NO}_{3}$ depends on soil characteristics that affect runoff. Mobilization with sediment for surface water transport of nitrogen depends on soil characteristics that affect runoff and detachment of soil particles;

Anthropogenic factors: Human activities can be categorized into a group of factors that also affect the potential for nitrogen to contaminate surface water resources.

1) Human activity contributes to greater accessibility and availability of nitrogen to surface water runoff. High levels of nitrogen in streams have been associated with septic system discharge in some areas, while high amount of $\mathrm{NH}_{3}$ have been observed downstream;

2) Cultivated land has been shown to contribute greater quantities to local streams compared to less intensive land use with continuous vegetation;

3) Rangeland, pastureland and grazed forestland have greater potential to serve as a source of nitrogen contamination of surface water compared to ungrazed areas.

\section{Nitrogen Fertilizers and Its Application}

Nitrogen fertilizers increase the yields of crops and are essential to food production in many parts of the world. Yet under certain circumstances, they pollute the environment and may contribute to fatal human illness [8,9] (Figure 2). Regional averages are about $30 \mathrm{~kg} \cdot \mathrm{N} \cdot \mathrm{ha}^{-1}$ for Asia, 15 $\mathrm{kg} \cdot \mathrm{N} \cdot \mathrm{ha}^{-1}$ for Latin America and $4 \mathrm{~kg} \cdot \mathrm{N} \cdot \mathrm{ha}^{-1}$ for Africa, compared with averages of $188 \mathrm{~kg} \cdot \mathrm{N} \cdot \mathrm{ha}^{-1}$ for Western Europe and $146 \mathrm{~kg} \cdot \mathrm{N} \cdot \mathrm{ha}^{-1}$ for Japan [10]. Much of this growth has been associated with the introduction of "Green Revolution" cereal varieties, which produce high yield but are dependent upon heavy applications of fertilizers. The rate, time and method of nitrogen application can affect the risk of nitrogen loss to surface water and groundwater. Leaching

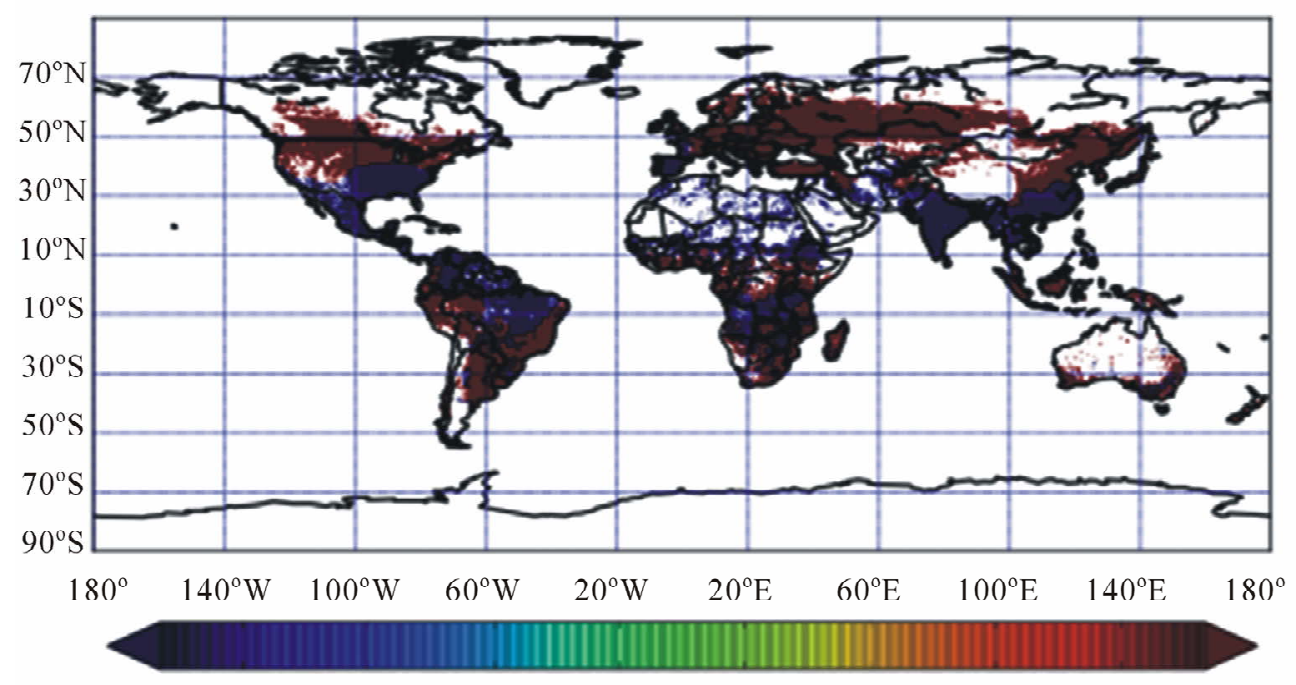

$6.80 \mathrm{e}+197.00 \mathrm{e}+197.20 \mathrm{e}+197.40 \mathrm{e}+197.60 \mathrm{e}+197.80 \mathrm{e}+198.00 \mathrm{e}+198.20 \mathrm{e}+19$

Figure 2. Distribution map showing global fertilizer consumption in year 2000 (in kg/ha). 
of nitrate to groundwater and nitrate in subsurface drainage is more concentrated with higher nitrogen rates. Nitrogen concentration in soil solution increases continuously with increasing nitrogen application rates and may increase more rapidly above the economic optimum nitrogen rate [11]. Manure is a valuable source of nitrogen for crop production. Nitrogen losses to water through leaching may be reduced with controlled-release fertilizers. Nitrate in irrigation water is used as efficiently with appropriate rates and during the period of active nitrogen uptake by the crop [12].

\section{Current Status of Nitrate Pollution: India}

Nitrogen consumption has been increasing tremendously since the introduction of high yielding cultivation of cereal crops. Role of fertilizer in cereal production became more evident after the green revolution and nitrate consumption drastically increase from year 1980 to 2008 [13]. The fertilizer statistics [13] shows the alarming concentration of consumption of nitrate is found in the state of Punjab and Haryana, which is about $139.6 \mathrm{~kg} / \mathrm{ha}$ and $125.6 \mathrm{~kg} / \mathrm{ha}$, respectively, whereas the lowest nitrate consumption is found in the state of Jammu and Kashmir (Figure 3). It is also reported that the ratio of deep to shallow (25 - $50 \mathrm{~m}$ ) wells is 1:100 in Punjab and Haryana, which implies that shallow groundwater is highly polluted water in these states. With the renewed focus on agricultural development in northern region, the demand for fertilizer, especially nitrate, is expected to increase at a faster rate [6]. The excessive use of nitrate results depletion of groundwater and surface water $[14,15]$. Groundwater may also be contaminated by other sources, including nonagricultural use of pesticides and fertilizers, and leaking underground storage tanks [4].

\section{Conclusions and Recommendation}

The rapidly expanding use of nitrogen in its reactive forms is linked to a growing number of environmental and social problems. Appropriate incentives and/or policies could affect substantial increases and effective use of nitrogen with existing knowledge and technologies.

1) Ensuring access of technology for the control of nitrogen losses during fossil fuel combustion and crop and animal production;

2) Increasing the efficiency of agricultural nitrogen use through education, best management practices, agro-environmental measures and incentives for adoption by farmers;

3) Implementing the emission reduction technology and developing sustainable energy options. The rapidly growing focus on biofuels as an alternative energy source must take into account changes in nitrogen cycling that will arise from shifts towards greater integration of biofuel and

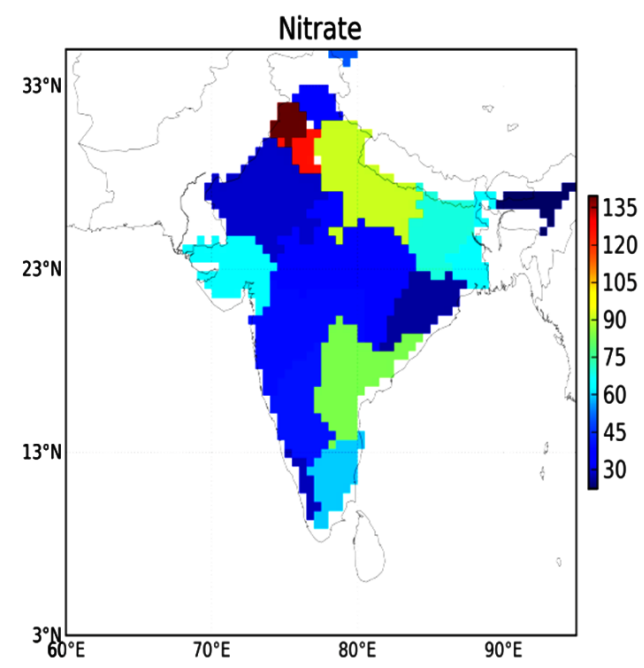

Figure 3. Consumption of nitrate in Indian state during 2003-2004 (in kg/ha).

feed production. Combined with other demands on agriculture, bio-energy production will require additional nitrogen to produce necessary biomass which could exacerbate existing issues related to the use of nitrogen in agricultural purposes;

4) Performing regional assessments and ensuring greater access of nitrogen-related issues as fertilizers;

5) Developing an integrated approach to nitrogen management and related issues.

\section{REFERENCES}

[1] P. M. Vitousek, J. Aber, R. W. Howarth, G. E. Likens, P. A. Matson, D. W. Schindler, W. H. Schlesinger and G. D. Tilman, "Human Alteration of the Global Nitrogen Cycle: Causes and Consequences," Issues in Ecology, Vol. 7, No. 1, 1997, pp. 1-16.

[2] P. N. Rekha, R. S. Kanwar, A. K. Nayak, C. K. Hoang, and C. H. Pederson, "Nitrate Leaching to Shallow Groundwater Systems from Agricultural Fields with Different Management Practices," Journal of Environmental Monitoring, Vol. 13, No. 9, 2011, pp. 2550-2558. doi:10.1039/c1em10120j

[3] R. F. Spalding and M. E. Exner, "Occurrence of Nitrate in Groundwater-A Review," Journal of Environmental Quality, Vol. 22, No. 3, 1993, pp. 392-402. doi:10.2134/jeq1993.00472425002200030002x

[4] A. Agrawal, R. S. Pandey and B. Sharma, "Water Pollution with Special Reference to Pesticide Contamination in India," Journal of Water Resource and Protection, Vol. 2, No. 5, 2010, pp. 432-448. doi:10.4236/jwarp.2010.25050

[5] J. A. Delgado and W. Bausch, "Potential use of Precision Conservation Techniques to reduce nitrate leaching in Surface Waters," Journal of Environmental Quality, Vol. 60, No. 6, 2005, pp. 379-387.

[6] A. P. Gupta, "Nitrogen Use Scenario of India," Science in 
China Series C: Life Sciences, Vol. 48, Suppl. 2, 2005, pp. 921-927.

[7] J. K. Bohlke, "Groundwater Recharge and Agricultural Contamination," Hydrogeology Journal, Vol. 10, No. 1, 2002, pp. 153-179. doi:10.1007/s10040-001-0183-3

[8] US National Research Council (USNRC), "The Health Effects of Nitrate, Nitrite and N-Nitroso Compounds," National Academy Press, Washington DC, 1981.

[9] Food and Agriculture Organization of India, "Total Nitrogen Fertilizer Dataset (1981- 2000),” 2004.

[10] G. R. Conway and J. N. Pretty, "Fertilizer Risks in the Developing Countries," Nature, Vol. 334, No. 21, 1988, pp. 207-208. doi:10.1038/334207a0

[11] P. A. Lawlor, M. J. Helmers, J. L. Baker, S. W. Melvin, and D. W. Lemke, "Nitrogen Application Rate Effects on Corn Yield and Nitrate-Nitrogen Concentration and Loss in Sub-Surface Drainage," ASAE Paper No. 052025, American Society of Agricultural Engineers, St. Joseph, 2005.
[12] D. L. Dinnes, D. L. Karlen, D. B. Jaynes, T. C. Kaspar, J. L. Hatfield, T. S. Colvin and C. A. Cambardella, "Nitrogen Management Strategies to Reduce Nitrate Leaching in Tile-Drained Midwestern Soils," Agronomy Journal, Vol. 94, No. 1, 2002, pp. 153-171. doi:10.2134/agronj2002.0153

[13] Fertilizer Association of India (FAI), "The Fertilizer Statistics 2008-2009," Fertilizer Association of Punjab, India, 2008.

[14] G. D. Aggarwal, S. K. Lunkad and T. Malkhed, "Diffuse Agricultural Nitrate Pollution of Groundwaters in India," Water Science and Technology, Vol. 39, No. 3, 1999, pp. 67-75. doi:10.1016/S0273-1223(99)00033-5

[15] A. Khajuria, S. Yoshikawa and S. Kanae, "Estimation and Prediction of Water Availability and Water Withdrawal in India," Journal of Japan Society of Civil Engineers, Ser. B1 (Hydraulic Engineering), Vol. 69, No. 4, 2013, pp. I_145I_150. 